Burt, A. J., F. Cagua, C. Sanchez, L. Calabrese, J. van de Crommenacker, J. McClelland, N. Shah, H. Richards, and N. Bunbury. 2021. Combining monitoring data from multiple sites to assess population status and trends of White-tailed Tropicbirds (Phaethon lepturus) in the Seychelles. Avian Conservation and Ecology 16(2):28. https://doi.org/10.5751/ACE-01858-160228

Copyright (C) 2021 by the author(s). Published here under license by the Resilience Alliance.

Research Paper

\title{
Combining monitoring data from multiple sites to assess population status and trends of White-tailed Tropicbirds (Phaethon lepturus) in the Seychelles
}

\author{
April J. Burt ${ }^{1,2}$ (D) , Fernando Cagua ${ }^{1,3}$, Cheryl Sanchez ${ }^{1,4,5}$, Licia Calabrese ${ }^{6}$, Janske van de Crommenacker ${ }^{7}$, James McClelland ${ }^{8}$, \\ Nirmal Shah ${ }^{4}$, Heather Richards ${ }^{1,9}$ and Nancy Bunbury ${ }^{1,10}$ \\ ${ }^{1}$ Seychelles Islands Foundation, Victoria, Mahé, Seychelles, ${ }^{2}$ Department of Plant Science, University of Oxford, Oxford UK, \\ ${ }^{3}$ Centre for Integrative Ecology, School of Biological Sciences, University of Canterbury, Christchurch, New Zealand, ${ }^{4}$ Nature \\ Seychelles, Centre for Environment and Education, Roche Caiman, Mahé, Seychelles, ${ }^{5}$ Department of Biology, University of Pisa, \\ Italy, ${ }^{6}$ Island Conservation Society, Pointe Larue, Mahé, Seychelles, ${ }^{7}$ Green Islands Foundation, Victoria, Mahé, Seychelles, \\ ${ }^{8}$ Cousine Island Company Limited, Victoria, Mahé, Seychelles, ${ }^{9}$ The Royal Society for the Protection of Birds (RSPB), Sandy, \\ Beddfordshire, UK, ${ }^{10}$ Centre for Ecology and Conservation, University of Exeter, Cornwall Campus, Penryn, UK
}

\begin{abstract}
Seabirds, being long-lived top-level marine predators, are often considered to be valuable environmental indicators. With growing evidence of seabird declines worldwide, it is essential to monitor changes in populations and determine drivers of change. The Seychelles Archipelago supports the greatest abundance of seabirds in the tropical Indian Ocean, but regional seabird population breeding success and trend data are not readily available despite multi-year data collection at several locations. Here we use monitoring data on White-tailed Tropicbirds (Phaethon lepturus) in the Seychelles to present the first nation-wide assessment of the status and trends of breeding success at five key sites. Mean annual breeding success was 15\% for Aldabra Atoll in the southern Seychelles and $33-55 \%$ in the inner islands (Aride, Cousine, Denis, and Cousin). In the inner islands there are indications of potential population declines (inferred from declining nesting activity rates at Aride), despite stable and comparatively high breeding success. This contrasts with Aldabra where nesting activity has been relatively stable, but a decline in breeding success is causing concern. Our study highlights clear priorities for management of P. lepturus populations in the Seychelles; the causes of the declines in $P$. lepturus breeding population at Aride and breeding success at Aldabra should be a focus of future research and monitoring. We propose the adoption of standardized monitoring programs and increased site coverage across the Seychelles and the broader Western Indian Ocean. This, coupled with increased pooling of data and regular analysis, will strengthen the collective effort toward the conservation management of this and other seabird species within this global seabird hotspot.
\end{abstract}

\section{Regroupement de données de suivis provenant de plusieurs sites pour évaluer l'état et la tendance des populations de Phaétons à bec jaune (Phaethon lepturus) aux Seychelles}

RESUME_. Les oiseaux marins, prédateurs de haut niveau trophique et de longue durée de vie, sont souvent considérés comme de précieux indicateurs environnementaux. Compte tenu de l'accumulation d'indications penchant vers la diminution des oiseaux marins dans le monde entier, il est essentiel de surveiller les changements dans les populations et de déterminer leurs facteurs sous-jacents. L'archipel des Seychelles abrite la plus grande abondance d'oiseaux marins de l'océan Indien tropical, mais il y a peu de données régionales sur le succès de reproduction et la tendance des populations d'oiseaux marins malgré la collecte de données pluriannuelles à plusieurs endroits. Dans le présent article, nous avons utilisé les données de suivis des Phaétons à bec jaune (Phaethon lepturus) aux Seychelles pour présenter la première évaluation à l'échelle nationale du statut et de la tendance du succès de reproduction à cinq sites clés. Le succès annuel moyen de reproduction était de $15 \%$ pour l'atoll d'Aldabra dans le sud des Seychelles et de 33-55 \% dans les îles intérieures (Aride, Cousine, Denis et Cousin). Dans les îles intérieures, des indications laissent entrevoir une baisse potentielle de la population (déduite de la baisse du taux d'activité de nidification à Aride), malgré un succès de reproduction stable et comparativement élevé. Ce résultat contraste avec Aldabra, où l'activité de nidification a été relativement stable, mais où la baisse du succès de reproduction est préoccupante. Notre étude révèle des priorités claires pour la gestion des populations de P. lepturus aux Seychelles; les causes de la baisse de la population nicheuse de P. lepturus à Aride et du succès de reproduction à Aldabra devraient faire l'objet de recherches et de suivis. Nous préconisons l'adoption de programmes de suivis normalisés et une couverture accrue de sites aux Seychelles et dans l'ensemble de l'océan Indien occidental. Cette proposition, associée à une mise en commun accrue des données et à leur analyse régulière, renforcera l'effort collectif pour la gestion de la conservation de cette espèce et d'autres espèces d'oiseaux marins dans ce lieu d'intérêt mondial pour les oiseaux marins.

Key Words: breeding success; Indian Ocean; population trends; seabird monitoring 


\section{INTRODUCTION}

The evidence for declines in both ocean health and seabird populations is unequivocal; just $13 \%$ of the world's oceans are relatively unaffected by human activity (Jones et al. 2018), and seabirds are now considered more threatened than any other comparable group of birds (Dias et al. 2019). Being long-lived top marine predators, seabirds are considered valuable environmental indicators (Einoder 2009). When monitored, they provide both a measure of health of that species as well as an indication of the overall state of the surrounding ecosystem (Piatt et al. 2007, Parsons et al. 2008).

The Western Indian Ocean (WIO) region has recently been identified by scientists as a key area to prioritize for the conservation of global marine biodiversity in the face of the climate crisis (Ramírez et al. 2017). The Seychelles support the greatest abundance of tropical seabirds in the Indian Ocean: the total is estimated to be approximately 3.4 million pairs (Le Corre et al. 2012) of 16 breeding species. The Seychelles islands are the main breeding ground for White-tailed Tropicbirds (Phaethon lepturus), with an estimated 6500 breeding pairs, and $56 \%$ of the WIO breeding population (Le Corre et al. 2012). Breeding populations of this species are monitored on a number of Seychelles islands, primarily because P. lepturus is one of the most ubiquitous seabird species and easily accessible to monitor. In addition, it is considered by conservation practitioners to be an important indicator species (Burger and Lawrence 2000a), whose status reflects or predicts the condition of the broader marine environment.

Phaethon lepturus are pelagic seabirds that undertake long foraging trips, feeding mainly on surface-dwelling prey, such as flying fish and squid (Schreiber and Clapp 1987, Catry et al. 2009). Its niche foraging strategy limits its rate of provisioning when these food sources are scarce (Schaffner 1990) and therefore directly relates to chick rearing (or breeding) success. Additionally, P. lepturus' ground-nesting breeding strategy is highly dependent on habitat integrity and is susceptible to environmental perturbations such as climatic events (Ancona et al. 2011) and invasive alien species (Russell and le Corre 2009). To use P. lepturus as an indicator of broader scale environmental changes, the factors influencing adult survival and breeding success must be identified and understood by those designing and conducting monitoring programs. Consolidating P. lepturus breeding population monitoring data therefore has the potential to be a valuable tool for managers of marine ecosystems.

With 115 islands stretching across an exclusive economic zone of 1.4 million $\mathrm{km}^{2}$, the Seychelles form a substantial part of the WIO region. Biodiversity monitoring programs are widely used across the Seychelles and can form an integral role in informing conservation management. However, despite the intensive efforts on various Seychelles islands, region-wide coordination of monitoring efforts is challenging on account of the high number and range of management authorities with varying management priorities. Determining broader trends, e.g., at national and regional scales, in population and breeding success, rather than island-by-island trends, of such a key seabird species is an essential step to facilitate effective management of this species and ultimately to provide better insight into the health of the surrounding ocean.
Although P. lepturus is listed as of "Least Concern" on the International Union for Conservation of Nature and Natural Resources (IUCN) red list, the species is suspected to be in decline on account of predation by invasive alien species at nesting sites (IUCN 2016). Seabird populations in the Seychelles have been threatened by habitat loss, invasive alien predators, and overutilization of seabirds and their eggs as a food source. Expanding fisheries activity and climate change also pose threats (Rocamora and Skerrett 2001, Bristol 2007). Here, for the first time, we compile multi-site monitoring data of P. lepturus in the Seychelles to (1) establish and compare breeding success between different islands; (2) assess nation-wide trends in breeding success and nesting activity as a proxy for population trends; and (3) identify breeding seasonality. We use these results to determine the population status of P. lepturus in the Seychelles and make recommendations to both improve monitoring effectiveness at a national level and establish whether the species is truly an indicator of broader ecosystem health.

\section{MATERIAL AND METHODS}

\section{Study sites and species}

We analyzed data from five sites in the Seychelles (Fig. 1, Table 1), including the four main monitoring sites for P. lepturus (Aldabra Atoll, Cousin Island, Cousine Island, and Aride Island) as well as Denis Island, where little was known about the $P$. lepturus population. The islands vary in size, geomorphology, elevation, protection status, management type, predator threats, and estimated $P$. lepturus population size (Table 1). Although $P$. lepturus also breed on other islands in the Seychelles (e.g., Frégate Island, Silhouette Island, North Island, and Bird Island; Skerrett et al. 2001), most are not routinely monitored. Each of the monitoring programs was managed independently, although they were based on locally developed guidelines (Burger and Lawrence $2000 \mathrm{~b}$ ), and they vary in duration, area covered, and methods (Table 2).

On rat- and cat-free islands (i.e., all sites except Aldabra), $P$. lepturus prefer to nest on bare, scratched patches inside rock or log cavities or next to vertical structures such as trees, boulders, or cliffs, laying one egg that both parents take turns to incubate (Prys-Jones and Peet 1980, Phillips 1987). On Aldabra, tropicbird nesting is restricted to limestone islets in the lagoon or coastal outcrops, and nest sites are predominantly crevices in the limestone. Although cats are present on some of Aldabra's islands, they are not present on or close to the tropicbird nesting areas. On Cousin Island, egg incubation is $40-41$ days, with a mean incubation shift length by parents of 6.6 days and fledging age of 67-89 days (mean 76.5 days; Phillips 1987).

\section{Monitoring}

On all islands, monitoring areas were visited and new nests searched for every 2-14 days. The area surveyed, the monitoring program duration, and the methods varied between islands (Table 2). Specifically, on Cousin Island, an annual or bi-annual snapshot survey was conducted whereby 100 nests at egg stage were chosen and followed to record nesting outcome. We focused on two metrics: breeding success (\% nests that fledged a chick) and nesting activity (the number of new nests). A nesting $P$. lepturus was defined as an adult incubating an egg or brooding a chick. 
Table 1. Details of the five Phaethon lepturus breeding study sites in the Seychelles.

\begin{tabular}{|c|c|c|c|c|c|c|c|c|}
\hline Site & Protection status & $\begin{array}{c}\text { Land } \\
\text { area (ha) }\end{array}$ & $\begin{array}{l}\text { Geomor- } \\
\text { phology }\end{array}$ & Location & Management & $\begin{array}{l}\text { Population } \\
\text { estimates }\end{array}$ & Potential nest predators & $\begin{array}{l}\text { Other disruptive }^{\dagger} \\
\text { species or factors }\end{array}$ \\
\hline Aldabra & $\begin{array}{l}\text { UNESCO } \\
\text { World Heritage } \\
\text { site (1982); } \\
\text { Special Reserve } \\
\text { (1975) }\end{array}$ & 15,254 & Coralline & $\begin{array}{l}9.2255^{\circ} \mathrm{S} \\
46.1310^{\circ} \mathrm{E}\end{array}$ & Public Trust & $\begin{array}{l}2000 \text { pairs } \\
\text { (Diamond } \\
\text { 1975) }\end{array}$ & $\begin{array}{l}\text { All able to access the islets: black rat } \\
\text { (Rattus rattus), Gray Heron (Ardea } \\
\text { cinerea), Aldabra Drongo }{ }^{\mathrm{A}} \text { (Dicrurus } \\
\text { aldabranus), coconut crab }{ }^{1} \text { (Birgus } \\
\text { latro), Pied Crow (Corvus albus) }\end{array}$ & $\begin{array}{l}\text { Red-tailed Tropicbirds }{ }^{\mathrm{A}} \\
\text { (Phaethon rubricauda); } \\
\text { occasional tidal } \\
\text { inundation of nest sites }\end{array}$ \\
\hline Aride & $\begin{array}{l}\text { Special Reserve } \\
\text { (1979) }\end{array}$ & 74 & Granitic & $\begin{array}{l}4.2000^{\circ} \mathrm{S} \\
55.6667^{\circ} \mathrm{E}\end{array}$ & NGO & $\begin{array}{l}1446 \text { pairs } \\
\text { (Bowler et al. } \\
\text { 2006) }\end{array}$ & $\begin{array}{l}\text { Wright's skink }{ }^{\mathrm{B}} \text { (Trachylepis wrightii), } \\
\text { Seychelles Fody }{ }^{\mathrm{B}} \text { (Foudia sechellarum), } \\
\text { house mouse (Mus musculus) }\end{array}$ & $\begin{array}{l}\text { Bird-catcher tree }{ }^{2} \\
\text { (Pisonia grandis, ticks, } \\
\text { shearwaters }{ }^{\mathrm{B}}\end{array}$ \\
\hline Cousin & $\begin{array}{l}\text { Nature Reserve } \\
(1969) \\
\text { Special Reserve } \\
(1975)\end{array}$ & 27 & Granitic & $\begin{array}{l}4.3314^{\circ} \mathrm{S} \\
55.6631^{\circ} \mathrm{E}\end{array}$ & NGO & $\begin{array}{l}2110 \text { pairs } \\
\text { (Burger and } \\
\text { Lawrence } \\
2000 \text { b) }\end{array}$ & $\begin{array}{l}\text { Wright's skink }{ }^{\mathrm{B}} \text {, Seychelles Fody }{ }^{\mathrm{B}} \text {, } \\
\text { ghost } \text { crabs }^{3} \text { (Ocypode spp.) }\end{array}$ & $\begin{array}{l}\text { Pisonia grandis } \\
\text { shearwaters }^{\mathrm{B}}\end{array}$ \\
\hline Cousine & $\begin{array}{l}\text { None, private } \\
\text { resort island }\end{array}$ & 26 & Granitic & $\begin{array}{l}4.3500^{\circ} \mathrm{S} \\
55.6333^{\circ} \mathrm{E}\end{array}$ & Private & $\begin{array}{l}450-850 \text { pairs } \\
\text { (Malan et al. } \\
\text { 2009) }\end{array}$ & $\begin{array}{l}\text { Wright's skink }{ }^{\mathrm{B}} \text {, Seychelles Fody, } \\
\text { ghost crabs, Seychelles Magpie-Robin } \\
\text { (Copsychus sechellarum) }\end{array}$ & $\begin{array}{l}\text { Pisonia grandis, giant } \\
\text { tortoises }^{\mathrm{B}} \text { (Aldabrachelys } \\
\text { gigantea }), \text { shearwaters }^{\mathrm{B}}\end{array}$ \\
\hline Denis & $\begin{array}{l}\text { None, private } \\
\text { resort island }\end{array}$ & 140 & Sand cay & $\begin{array}{l}3.8000^{\circ} \mathrm{S} \\
55.6667^{\circ} \mathrm{E}\end{array}$ & Private & $\begin{array}{l}\sim 40 \text { pairs (this } \\
\text { study) }\end{array}$ & $\begin{array}{l}\text { None perceived; cats removed in } 2000 \text {, } \\
\text { rats removed in } 2002\end{array}$ & \\
\hline
\end{tabular}

Because clutch size is one egg in this species, we calculated breeding success as the proportion of nests encountered with an egg that resulted in a fledgling. Nest status was determined by comparing the nest stage of two consecutive visits. For example, if a nest was observed to have been occupied by an egg or a young (partially feathered) chick and was subsequently observed empty or with signs of predation/death, it was recorded as unsuccessful. Unsuccessful nests were scored as to whether failure occurred at egg or chick stage. We acknowledge that the gaps between nest checks may therefore over-estimate the number of attempts failing at egg stage if an egg hatched and the chick died before the next nest check, but observers searched the nest area for signs of chick predation or egg remnants to inform decisions on nest failure stage. Conversely, if a nest was observed to be occupied by a nearfledged (fully feathered) chick and found empty in a subsequent visit, without signs of predation/death, it was assumed that the chick had fledged and was recorded as successful.

Nesting activity was defined as the number of new nests encountered per month; we used "new nest" rather than "total active nests per month" to avoid potential pseudo-replication from one nesting attempt being included across several months. Although we use "new nests" as a proxy for population trends, we acknowledge that this dynamic between number of new nests and failed nests is sensitive to patterns of re-nesting behavior. We calculated nesting activity per month for the sites in which all nests were monitored within a specific area (Aride, Aldabra) or for a set number of known nesting sites (Cousine). For these sites, observers checked all known nesting sites/cavities within the specified area to ensure survey/observer effort remained constant; nesting attempts (sites/cavities) were marked for ease of following (Burger and Lawrence 2000a). This nesting activity can be used as a proxy for breeding population size, assuming that the area monitored and the effort remained constant over time. All nests were dated from the first record. To avoid introducing potential bias, new nests were only included in the breeding success dataset if they were first found at incubation stage (i.e., nests found at chick stage were excluded). Nevertheless, across all sites, more than $95 \%$ of the nests were first encountered at egg stage.
Fig. 1. Seychelles islands in the Western Indian Ocean region (left), the four Phaethon lepturus monitoring site locations in the inner Seychelles (Cousin, Aride, Cousine, and Denis; top right), and Aldabra Atoll (bottom right) in the southern Seychelles, with specific monitoring area of Aldabra shown (inset).

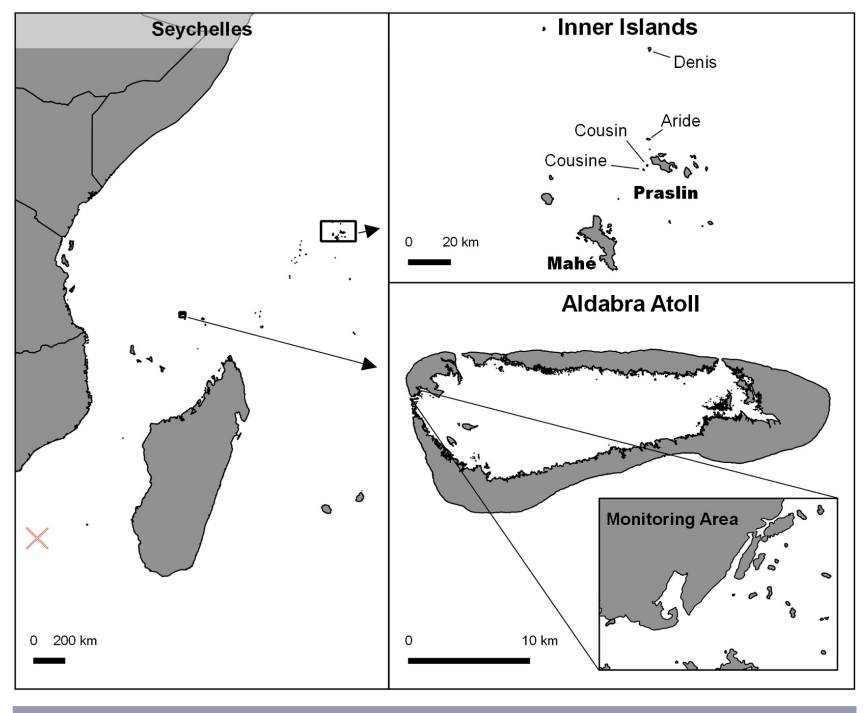

\section{Data analysis}

We treated breeding success as a binomial variable (successful nest $=1$; unsuccessful $=0$ ) and calculated the mean breeding success as the percentage of successful nests at each site. We also calculated the proportion of unsuccessful nests that failed during egg stage compared to those that failed during chick stage. At the three sites where monitoring effort was continuous for 4-10 years (Aldabra, Aride, and Cousine), we also investigated long-term and seasonal trends using a set of generalized additive models (GAM) with a binomial error structure and breeding success as 
Table 2. Details of Phaethon lepturus monitoring programs at the five study sites in the Seychelles, including the most recent published assessment of breeding success.

\begin{tabular}{|c|c|c|c|c|c|c|c|}
\hline Site & $\begin{array}{l}\text { Area } \\
\text { monitored } \\
\text { (ha) }\end{array}$ & $\begin{array}{l}\text { Monitoring } \\
\text { data } \\
\text { included }\end{array}$ & $\begin{array}{c}\text { Frequency of } \\
\text { monitoring }\end{array}$ & Methods & Nest distribution & $\begin{array}{l}\text { Nest description and } \\
\text { habitat type }\end{array}$ & Last assessment \\
\hline Aldabra & 0.4 & $\begin{array}{l}\text { Feb 2009- } \\
\text { Nov } 2016\end{array}$ & $\begin{array}{l}\text { Continuous year-round } \\
\text { monitoring, every } 2 \\
\text { weeks }\end{array}$ & $\begin{array}{l}\text { Entire monitoring area } \\
\text { searched, all new nests } \\
\text { recorded and tagged; nests } \\
\text { visited on subsequent } \\
\text { surveys until nest outcome } \\
\text { determined }\end{array}$ & $\begin{array}{l}\text { Only on limestone islets or } \\
\text { coastal outcrops; } \\
\text { monitored on } 13 \text { small } \\
\text { lagoon islets and an } \\
\text { outcrop of Picard Island }\end{array}$ & $\begin{array}{l}\text { Limestone cavities or } \\
\text { cavities in dense vegetation } \\
\text { on small islets and coastal } \\
\text { outcrops }\end{array}$ & $\begin{array}{l}\text { Prys-Jones and } \\
\text { Peet } 1980\end{array}$ \\
\hline Cousin & 20 & $\begin{array}{l}\text { 1999, } \\
2009-2016\end{array}$ & $\begin{array}{l}1-2 \times / \text { year beginning } \\
\text { Feb and/or July, nests } \\
\text { visited every } 3-4 \text { days }\end{array}$ & $\begin{array}{l}\text { Survey effort defined by a } \\
\text { set number of nests rather } \\
\text { than a specific area; } \sim 100 \\
\text { nests at incubation stage } \\
\text { tagged; nests visited on } \\
\text { subsequent surveys until } \\
\text { nest outcome determined }\end{array}$ & $\begin{array}{l}\text { Ubiquitous, predominantly } \\
\text { monitored on plateau } \\
\text { along coast and inland }\end{array}$ & $\begin{array}{l}\text { Bare scratched patches } \\
\text { inside rock or log cavities } \\
\text { or against tree roots or } \\
\text { boulders }\end{array}$ & Phillips 1987 \\
\hline Aride & 5 & $\begin{array}{l}\text { Jan 2011- } \\
\text { Dec } 2016\end{array}$ & $\begin{array}{l}\text { Continuous year-round } \\
\text { weekly monitoring }\end{array}$ & $\begin{array}{l}\text { Entire monitoring area } \\
\text { searched, all new nests } \\
\text { recorded and tagged; nests } \\
\text { visited on subsequent } \\
\text { surveys until nest outcome } \\
\text { determined }\end{array}$ & $\begin{array}{l}\text { Ubiquitous, only } \\
\text { monitored on coastal } \\
\text { plateau along coastal and } \\
\text { inland areas of forest }\end{array}$ & $\begin{array}{l}\text { Bare scratched patches } \\
\text { inside rock or log cavities } \\
\text { or against tree roots or } \\
\text { boulders }\end{array}$ & $\begin{array}{l}\text { Ramos et al. } \\
2005\end{array}$ \\
\hline Cousine & $\sim 3.5$ & $\begin{array}{l}\text { Jan } 2007- \\
\text { Dec } 2011\end{array}$ & $\begin{array}{l}\text { Continuous year-round } \\
\text { weekly monitoring }\end{array}$ & $\begin{array}{l}90 \text { fixed nest sites } \\
\text { monitored continuously; all } \\
\text { new nests tagged and } \\
\text { visited on subsequent } \\
\text { surveys until nest outcome } \\
\text { determined }\end{array}$ & $\begin{array}{l}\text { Ubiquitous, only } \\
\text { monitored on accessible } \\
\text { eastern side }\end{array}$ & $\begin{array}{l}\text { Bare scratched patches } \\
\text { inside rock or log cavities } \\
\text { or against tree roots or } \\
\text { boulders }\end{array}$ & $\begin{array}{l}\text { Malan et al. } \\
2009\end{array}$ \\
\hline Denis & 20 & $\begin{array}{l}\text { Nov 2015- } \\
\text { Sept } 2016\end{array}$ & $\begin{array}{l}\text { Continuous year-round } \\
\text { monitoring, every } 2 \\
\text { weeks }\end{array}$ & $\begin{array}{l}\text { Entire monitoring area } \\
\text { searched, all new nests } \\
\text { recorded and tagged; nests } \\
\text { visited on subsequent } \\
\text { surveys until nest outcome } \\
\text { determined }\end{array}$ & $\begin{array}{l}\text { Ubiquitous, more } \\
\text { abundant in forest; } \\
\text { monitored in all areas } \\
\text { except coconut plantation }\end{array}$ & $\begin{array}{l}\text { Mostly in tree cavities or } \\
\text { on forked branches/trunks, } \\
\text { some on ground amongst } \\
\text { tree roots or boulders }\end{array}$ & $\mathrm{n} / \mathrm{a}$ \\
\hline
\end{tabular}

the response variable. At the remaining two sites (Cousin and Denis) we only calculated annual breeding averages because monitoring efforts were seasonal (Cousin) or monitoring was of short duration ( $<1$ year; Denis). To quantify temporal trends, we included "date" as a continuous smooth variable. This date (year and month) allowed us to explore potential non-linear changes in breeding success over time.

We followed a similar approach when analyzing the nesting activity on Aldabra, Aride, and Cousine. Here, we used a set of GAMs with a Gaussian error structure in which the response variable was the number of new nests recorded per month at a particular site. As in the breeding success models, date was included as a smooth variable. Because seabird nesting patterns generally have a strong seasonal component (Diamond and PrŷsJones 1986, Šúr et al. 2013), we included month as a continuous smooth variable to control for seasonal variation in nesting activity. All models were fitted using the MGCV package in R 3.2 (R Core Team 2013).

Model diagnostics indicated that the dimensions used for the smooth terms were adequate in all sites for both breeding success and nesting activity. On Aride and Cousine where breeding success was aggregated on a monthly basis and therefore possible to analyze residual plots, we found no patterns that would suggest a violation of model assumptions. The residuals of the nest activity models suggest that there might be small amounts of overdispersion and therefore we are cautious in interpreting the results.

\section{RESULTS}

Mean annual breeding success was 15\% for Aldabra and 33-55\% in the inner islands (Aride, Cousine, Denis, and Cousin; Table 3). The values from Denis are based on 11 months of monitoring and are therefore a monthly mean rather than annual mean. At all sites, nests were more likely to fail during egg than chick stage (Table 3). Breeding success did not show strong seasonality and remained constant over the years of monitoring at all sites except Aldabra, where a significant decline was observed between 2009 and $2016\left(\mathrm{df}=1, \mathrm{x}^{2}=7.61, \mathrm{p}<0.05\right.$; Fig. 2A, Table 4).

Nesting activity showed no significant variation between years at Aldabra (Table 4), whereas it increased on Cousine $\left(\mathrm{df}=1.9, \mathrm{x}^{2}\right.$ $=29.2, p<0.05 ;$ Fig. 2A, Table 4) and strongly declined on Aride $\left(\mathrm{df}=1.6, \mathrm{x}^{2}=35.2, \mathrm{p}<0.001\right.$; Fig. 2B, Table 4). Aride's nesting activity also showed significant seasonal variation $\left(\mathrm{df}=3.8, \mathrm{x}^{2}=\right.$ 49.1, p < 0.001; Fig. 3, Table 4) with clear peaks during September-October and April-June, and a low in DecemberJanuary. Seasonality in nesting activity showed a similar, though weaker pattern on Cousine $\left(\mathrm{df}=3.1, \mathrm{x}^{2}=12.7, \mathrm{p}=0.003\right.$; Fig. 3 , Table 4) and was virtually non-existent on Aldabra.

\section{DISCUSSION}

\section{Breeding success and temporal trends}

Phaethon lepturus have been monitored continuously on four islands across the Seychelles for up to 13 years. Monitoring duration varied by island and additional programs have been 
Table 3. Success of Phaethon lepturus nests monitored annually at each study site: total and annual nests monitored, mean annual breeding success (\% successful nests), and the proportion of nests that failed at egg or chick stage at each site.

\begin{tabular}{lccccccc}
\hline \hline Site & Monitoring duration & $\begin{array}{c}\text { Total nests } \\
\text { monitored }\end{array}$ & $\begin{array}{c}\text { Total \# nests } \\
\text { successful }\end{array}$ & $\begin{array}{c}\text { Annual mean \# } \\
\text { nests monitored } \pm \\
\text { StDev) }\end{array}$ & $\begin{array}{c}\text { Annual mean \# } \\
\text { nests successful }\end{array}$ & $\begin{array}{c}\text { Of failed nests, \% } \\
\text { failed at egg/chick } \\
\text { stage }\end{array}$ & $\begin{array}{c}\text { Annual mean } \\
\text { breeding success }( \pm \\
\text { SE) }\end{array}$ \\
\hline Aldabra & Feb 2009-Nov 2016 & 308 & 47 & $42( \pm 9.8)$ & 6.4 & $66 / 34(1.9: 1)$ & $15.2 \%( \pm 2.29)$ \\
Aride & $2009-2016$ & 1033 & 416 & $172( \pm 35)$ & 69 & $62 / 38(1.6: 1)$ & $40.2 \%( \pm 3.8)$ \\
Cousin & $1999,2009-2016$ & 880 & 318 & $97( \pm 3)$ & 35 & $64 / 36(1.7: 1)$ & $34.6 \%( \pm 4.04)$ \\
Cousine & Jan 2007-Dec 2011 & 537 & 261 & $107( \pm 25)$ & 52.2 & $72 / 28(2.6: 1)$ & $51.6 \%( \pm 2.9)$ \\
Denis & Nov 2015-Sept 2016 & 39 & 21 & $(39)$ & $(21)$ & $11 / 7(1.6: 1)$ & $53.8 \%( \pm 9.3)$ \\
\hline
\end{tabular}

Denis Island nest monitoring was conducted for 11 months so the data shown (in parentheses) is the 11-month mean.

Fig. 2. Long-term trends in (A) probability of breeding success on five islands in Seychelles and (B) nesting activity of new Phaethon lepturus. Grey bands indicate the corresponding standard error of the model predictions. Vertical bars indicate standard deviation for Denis Island.
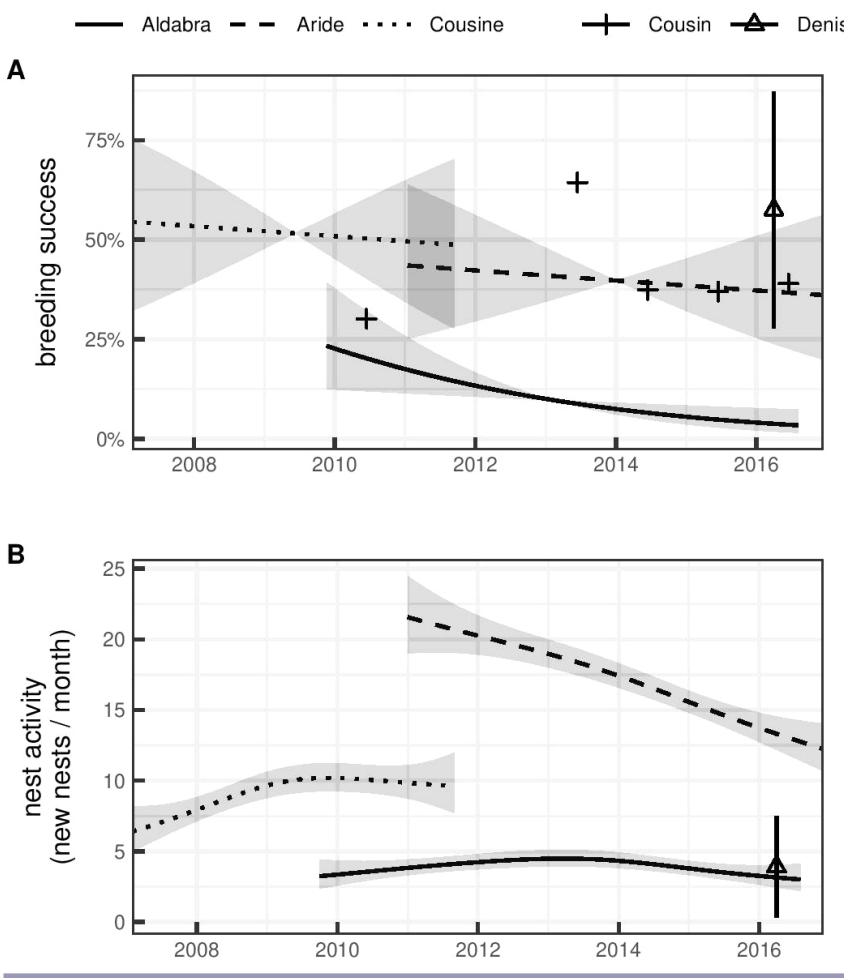

implemented on other islands more recently. We pooled these data to provide the first national assessment of breeding success and population trends for P. lepturus in the Seychelles. There was considerable variation in breeding success across sites (15-55\%), with the Aldabra population showing the lowest annual breeding success. Breeding success of P. lepturus in the inner Seychelles $(33-55 \%)$ is relatively high compared with records from elsewhere: $30 \%$ on Ascension Island (Stonehouse 1962) and 21\% on Cayo Luis Peia, Puerto Rico (Schaffner 1991). The highest breeding success recorded globally is in Bermuda, where success across eight islands averaged $70.6 \%$, and all sites are managed as nature reserves with active exclusion of mammalian predators (Madeiros
Table 4. Generalized additive model output for nesting rate and breeding success of Phaethon lepturus on three of the five islands included in this study. Term column: trend refers to change between years, and season refers to changes observed on an annual cycle (seasonality). Significant statistics are in bold. Note that the lack of year-round data collection on Cousin Island and the short duration of monitoring on Denis Island excluded them from this type of analysis.

\begin{tabular}{lllccc}
\hline \hline Model & Island & Term & e.d.f. & $\mathrm{X}^{2}$ & $p$ \\
\hline Success & Aldabra & season & 0.60 & 1.13 & 0.141 \\
& & trend & 1.00 & 7.61 & $\mathbf{0 . 0 0 6}$ \\
& Aride & season & 0.00 & 0.00 & 0.467 \\
& trend & 1.00 & 0.14 & 0.706 \\
& Cousine & season & 0.00 & 0.00 & 1.00 \\
& & trend & 1.00 & 0.06 & 0.802 \\
Nests & Aldabra & season & 0.64 & 1.17 & 0.151 \\
& & trend & 2.11 & 5.68 & 0.090 \\
& Aride & season & 3.78 & 49.1 & $<\mathbf{0 . 0 0 1}$ \\
& & trend & 1.60 & 35.2 & $<\mathbf{0 . 0 0 1}$ \\
& Cousine & season & 3.09 & 12.7 & $\mathbf{0 . 0 0 3}$ \\
& & trend & 1.99 & 9.25 & $\mathbf{0 . 0 1 4}$ \\
\hline
\end{tabular}

Fig. 3. Seasonality in nesting activity of Phaethon lepturus on Aldabra, Aride, and Cousine. Shaded areas indicate the standard error of the model predictions.

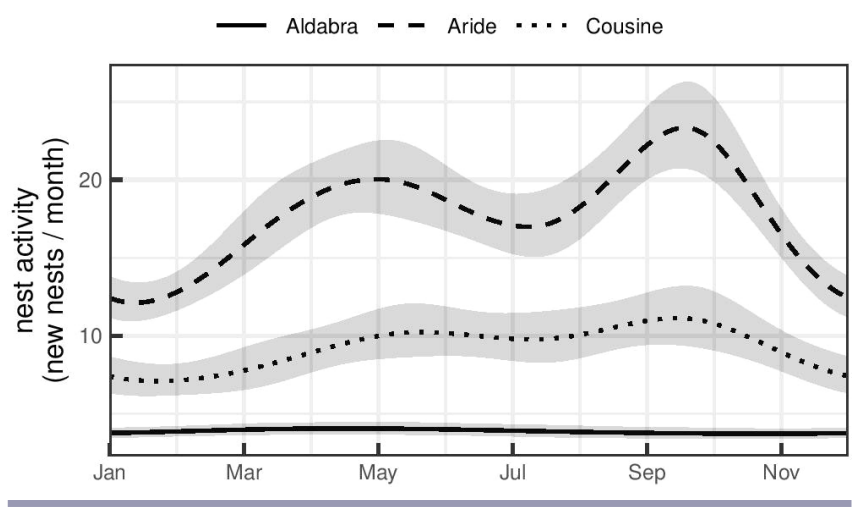

2008). Aldabra, despite its high protection status, has among the lowest records of $P$. lepturus breeding success worldwide, similar to that at Fernando de Noronha archipelago, also a UNESCO 
World Heritage site and protected area, in Brazil, the largest colony of P. lepturus in the South Atlantic (Leal et al. 2016). At Fernando de Noronha, between August 2011 and January 2012, only $14.3 \%$ of nests were successful, and predation at egg stage accounted for $50 \%$ of nest outcomes. The low success was attributed by the authors mainly to predation by native and nonnative predators, although this was not confirmed in their study, in which only one chick was observed to be predated by a crab (Leal et al. 2016). The lowest breeding success for P. lepturus has been recorded at Europa Island, also in the WIO, at $6.9 \%$ for nonrat-controlled habitats (Ringler et al. 2015), and local eradication of rats on one of Europa's islets increased breeding success of Red-tailed Tropicbirds (Phaethon rubricauda) to $79 \%$, i.e., 15 times higher than on the non-rat-controlled main island. Aldabra is the only site within this study that has invasive black rats (Rattus rattus) and many additional potential nest predators (Table 1) that may account for the low breeding success. This could be confirmed by setting camera traps at nest sites to observe nest failure events. The low breeding success recorded at Aldabra conforms to results from other studies where invasive predators are present and supports the claim that, in the case of White-tailed Tropicbirds, predation by invasive species, primarily rats (Russel and le Corre 2009, Sarmento et al. 2014), as well as native species (Phillips 1987, Schaffner 1991), is the main cause of nest failure in the Seychelles. We therefore conclude that for stable populations, it is likely that the differences observed in breeding success amongst the Seychelles islands are primarily due to the composition and abundance of local predators.

Breeding success trends in the inner Seychelles were stable over the monitoring period (Aride, Cousine, and Cousin), but Aldabra shows not only low annual breeding success but also a concerning decline over time. Earlier studies of P. lepturus at Aldabra reported breeding success to be much higher $30-35$ years ago in the same area $(47.5 \%$ in 1975, $\mathrm{n}=40$; [Diamond 1975]; 46\% in 1980, $\mathrm{n}=$ 39 [Prys-Jones and Peet 1980]). For Aldabra, all the known and potential predators listed (Table 1), except rats and Pied Crows (Corvus albus), are also monitored and none have shown increasing trends (SIF unpublished data). An increase in drought periods has been reported for Aldabra (Haverkamp et al. 2017); this may influence nest site conditions via reduced shading from vegetation, but is unlikely to have directly impacted $P$. lepturus breeding success on account of their choice of limestone crevices as sheltered nest sites rather than vegetation cover, which is preferred by the sympatric $P$. rubricauda. Sheltered nests like limestone crevices have more stable ambient temperatures (Hart et al. 2016), and site selection offsets difficulties imposed by the weather. However, the low-lying islets on which they nest may be increasingly impacted by tidal inundation because of increased storm surge and eventually sea-level rise (Rabbani et al. 2010). For Aldabra, we conclude that the monitoring program was sufficient to detect a decline in breeding success and, in combination with other monitoring, rules out several potential drivers of the decline. Further investigation into nest site competition, predation, and in particular food availability, should be prioritized to understand the drivers of breeding success decline on Aldabra.

The stable breeding success trends detected in the inner Seychelles islands from this study were reinforced when comparing breeding success records from previous studies at those sites. For example, we recorded an annual mean of $51.6 \%$ nesting success on Cousine compared to 25\% during 2003-2005 (Malan et al. 2009), showing a large increase, possibly as a result of forest habitat rehabilitation. Cousin averaged $33 \%$ breeding success in this study, compared to $36 \%$ in 1981-1983 (Phillips 1987), and Aride averaged 40.2\% here, compared to $21-37 \%$ in 1989-2002 (Ramos et al. 2005).

\section{Trends in nest activity}

At sites where the number of nests monitored was delineated by a set area (or number of cavities) that remained constant across monitoring years, we assessed trends in nesting activity over time. Nesting activity remained stable at Aldabra (2009-2016), showed a slight upwards trend at Cousine (2007-2011), and a continuous negative trend on Aride (2011-2016). A decline on Aride was previously reported; the nesting population of $P$. lepturus suffered an apparent decline of 60\% between 1989 and 1998 (Bowler et al. 2006). Our results, along with unpublished census data (Island Conservation Society Seychelles), show that this decrease has continued, with a rapid decline of $65 \%$ in nesting activity between 2011 and 2016.

The islands of Aride, Cousin, and Cousine are less than $15 \mathrm{~km}$ apart, and therefore their P. lepturus populations are likely to be affected by similar external factors, such as climate and food availability. The differences in monitoring periods used in this study between Cousine and Aride make it difficult to determine, without additional data, whether the decline in nesting activity on Aride is mirrored in these nearby populations. We recorded a slight upward trend in nesting activity at Cousine but this was during the four years prior to the data analyzed for Aride. One would expect, if the population decline — via adult mortality and/ or lack of recruitment to population - is caused by local factors on Aride itself, such as from nest-site predation, e.g., by skinks, fodies, or mice, or by poor food provisioning for chicks, e.g., frigatebird kleptoparasitism, that these would also influence breeding success. Previous studies at Aride have shown that breeding success was correlated with the El Niño Multivariate Index, i.e., El Niño events resulted in lower fledging success (Ramos et al.2005), and there was little evidence that productivity, i.e., breeding success, was influenced by local factors such as hard tick infestations or intra- and inter-specific competition. This coincides with our findings; breeding success on Aride remains relatively high and stable but this is evidently not enough to support population stability. Adult survival is considered the vital rate to which population dynamics for long-lived species like $P$. lepturus are most sensitive (Souchay et al. 2013). The decline in nesting activity previously recorded was attributed to annual adult survival, which was suggested not to be linked to interannual variability in oceanographic conditions, but potentially influenced by fruiting events of the coastal shrub, Pisonia grandis, which, overall, accounted for $23.2 \%$ of adult mortality (P. grandis produces sticky seeds that can accumulate on and eventually kill seabirds; Catry et al. 2009). Based on adult survival rates, the probability of extinction of this population was predicted to be $99 \%$ in 170 years (Catry et al. 2009). Active management was proposed and carried out by maintaining some areas free of $P$. grandis.

However, Pisonia grandis is native to the Seychelles and thrives in acidic, guano-enriched soils. It is common across Aride, Cousin, and Cousine, causing mortality in all seabird species that nest in 
its vicinity. Cousin, for example, has $69 \%$ P. grandis coverage (Hill 2002) and likewise suffers some $P$. grandis-induced mortality of $P$. lepturus adults. Management of $P$. grandis is fairly similar across these sites and includes raking away the seeds from certain areas. On Aride, a $1170-\mathrm{m}^{2}$ coastal strip was cleared of $P$. grandis between 2009 and 2011 and planted with other native trees. This management action appears to have had no positive impact on the nesting activity rate for Aride. It is therefore reasonable to conclude that, if $P$. grandis was the major cause of rapid adult mortality and subsequent reduction in nesting activity on Aride, it would have had similar effects on Cousin and Cousine, although little data exists to compare $P$. grandis extent and impact across these three sites. It is also unclear whether $P$. grandis affects fledged chicks (after they have left the nest but before they have left the island), which would result in lower population recruitment but not be detected by nesting success monitoring. Without additional evidence of site-driven mortality at Aride and data on P. lepturus population status on Cousine and Cousin for recent years, a precautionary approach is prudent. The decline in nesting activity on Aride is likely to be an indication of the health of the broader environment and may be similarly affecting the populations on Cousine and Cousin. To conclude, it remains unclear why the Aride breeding population is in decline; however, comparing data from multiple sites enables us to rule out several potential causes. Further collaborative research across the same time period is required to compare populations at Aride, Cousine, and Cousin to disentangle the factors influencing adult mortality and identify the driver of the declines on Aride, and possibly on other islands. Specifically, additional research into post-fledging survival, e.g., via mark and recapture and recording numbers of adults/fledglings affected by P.grandis, and comparisons of levels of $P$. grandis-induced mortality across these sites would be valuable, as well as compiling long-term census data.

\section{Nesting rate seasonality}

Marked seasonality in seabird nesting is often related to prey availability at certain times of year (Le Corre 2001, Jaeger et al. 2010). However, we found no nesting seasonality for P. lepturus on Aldabra, concurring with previous studies (Diamond 1975, Prys-Jones and Peet 1980), whereas inner island populations show varying levels of seasonality. Breeding seasonality differences between the inner Seychelles islands and Aldabra have been recorded previously for tern species (Diamond and Prŷs-Jones 1986); differences were associated with seasonal latitudinal movement of the divergence zone between the South Equatorial Current and the Equatorial Counter-Current, acting via correlated latitudinal shifts of prey species and surface-dwelling tuna abundance. The lack of seasonality at Aldabra suggests there may be an additional or alternative driver to nesting seasonality in the inner granitic islands. One potential factor is the level of shade at nest sites. Phillips (1987) reported that P. lepturus nesting against tree roots were sometimes exposed to direct sunlight, causing noticeable heat stress. Birds at these sites may have developed nesting seasonality to counteract the effects of this, avoiding heat stress during the dry season when shade cover is lowest. Our data supports this on Cousine and Aride, with peak nesting activity in October, which coincides with the start of the rainy season. If shade cover is indeed driving seasonality in nesting $P$. lepturus, the lack of nesting seasonality on Aldabra is likely because the species nests almost exclusively in well-sheltered limestone crevices, rather than the forest cover areas that dominate nesting sites on Cousine and Aride. In contrast, the Phaethon rubricauda), which nest in the same locations on Aldabra but in vegetation rather than limestone crevices, do exhibit pronounced nesting seasonality with peaks coinciding with the rainy season (SIF unpublished data). Whether the breeding seasonality differences between these two sympatric species at Aldabra is on account of nest site choice as suggested by Prys-Jones and Peet (1980) or driven by seasonal differences in prey availability as a result of different target prey is unclear. Another possibility is that $P$. lepturus is forced to breed year-round because the larger more dominant $P$. rubricauda is monopolizing the best breeding window. Data from other sites concur with $P$. lepturus breeding year-round (Stonehouse 1962, Le Corre 2001), but seasonal peaks vary from site to site (e.g., Raine et al. 2020).

\section{National conservation status and monitoring}

The five $P$. lepturus breeding sites in this study demonstrate the high level of commitment and resources allocated to monitoring this species in the Seychelles. Despite differences in methods and effort, the individual long-term monitoring programs fulfil the aim of determining temporal trends in breeding success at each site. Furthermore, the continuous year-round monitoring carried out at Aride, Aldabra, and Cousine, and recently begun on Denis Island, provide data on breeding seasonality as well as a continuous measure of nesting activity over time within the surveyed area. Although there was no overall consensus in breeding success trends, on account of the decline at Aldabra, the inner Seychelles populations show overall stable breeding success. However, population trends based on nesting activity over time were difficult to interpret with the current data because of the differences in monitoring methods and time frame across the sites. Although annual (some bi-annual) population censuses are conducted at Aride, Cousin, and Cousine, as well as other islands, these datasets have not yet been compiled and analyzed collectively. The information from these census trends would enable more accurate assessment of the current population status and trends of P. lepturus in the Seychelles, especially whether the nesting activity decline on Aride is seen on neighboring islands. Additionally, capture-mark-recapture methods should be added where possible because of the species' high fidelity to nesting areas (Leal et al. 2016) to provide information on adult survival.

This research provides information that can feed directly back into management decisions, such as where to focus research efforts and conservation resources. The causes of the declines in $P$. lepturus breeding population at Aride and breeding success at Aldabra should clearly be priorities for future research. Other actions that support tropicbird survival and breeding success, such as rat and cat eradications, should be prioritized.

We also highlight an important consideration when using species monitoring as an indicator of broader environmental changes; the effects of local drivers of breeding success and activity should, where possible, be distinguished from external factors such as climatic changes impacting prey availability. This could be achieved for P. lepturus by measuring local impacts such as predation levels, e.g., by setting up a camera trapping study to identify causes of nest failure and/or monitoring predator species trends, and habitat changes, e.g., by including a measure of nest site quality/type such as exposure level. Additional studies can be costly, but when set up collaboratively they are often more feasible; 
for example, cameras used to monitor nests can be passed on to other sites, bringing overall costs down and being more attractive for potential funders than a one-site project.

Based on the challenges we faced in compiling and analyzing these data, we can make several specific $P$. lepturus monitoring recommendations to managers. First, we strongly recommend survey effort to be delineated not by a fixed number of nesting attempts or nesting sites but by a set area that is representative of the main island habitat, and as large as is feasible to ensure monitoring effort consistency. Area-delineated monitoring is the most widely applied method in the Seychelles and enables a broader scope for analysis, resulting in a greater understanding of the changes in nest activity and nesting success over time. Second, maintaining continual year-round monitoring is preferential to snap-shot (seasonal) monitoring to ensure direct comparability across sites, to understand seasonal nuances, and to detect anomalies or changes. Finally, data storage/format varied greatly across sites and required substantial cleaning to enable analysis, therefore we highly recommend that analysisfriendly data spreadsheets or databases are adopted across sites, coupled with the development of an analysis script to facilitate regular on-site data visualization and analysis.

To build upon existing knowledge, maximize the investment of effort and resources, and improve the value of data for P. lepturus throughout the Seychelles and across the WIO region, we propose the adoption of a nation-wide monitoring plan with consideration for the spectrum of resources available across sites; regular reviewing and analysis of datasets to detect changes, implement actions, and monitor the effects of those actions; clear monitoring questions (e.g., What is the population status of P. lepturus? Does the implementation of this intervention have a positive impact on nesting success? What are the main causes of nest failure?) and objectives (e.g., detect trends in nesting success/activity; identify the main causes of nest failure; increase breeding success by reducing nest predation by rats); and a strong understanding of the factors influencing the ecosystem or population (Lindenmayer and Likens 2018), for example, climate, food availability, disturbance, and habitat changes. Although this study focuses on five sites, P. lepturus nests occur on many other Seychelles islands. Utilizing existing practitioner networks, such as the Seychelles and Indian Ocean Seabird Groups (Nature Seychelles 2021) to extend monitoring coverage to other sites and develop comparable monitoring programs will greatly strengthen the collective efforts of site managers to understand and protect this and other seabird species within this seabird hotspot.

Responses to this article can be read online at: https://www.ace-eco.org/issues/responses.php/1858

\section{Acknowledgments:}

We would like to thank the large number of contributing staff and volunteers for their assistance in monitoring of P. lepturus across the study sites over the years. This study was not funded but was made possible by the support and leadership of the Seychelles Islands Foundation and the annual Seychelles Seabird Group Forum. Thanks also to Annette Fayet, Gerard Rocomora, PierreAndre Adam, Jeanne Mortimer, Mark Brown, and Bronwyn and Stuart Dunlop for their valuable feedback on the manuscript prior to submission.

\section{LITERATURE CITED}

Ancona, S., S. Sánchez-Colón, C. Rodríguez, and H. Drummond. 2011. El Niño in the warm tropics: local sea temperature predicts breeding parameters and growth of Blue-footed Boobies. Journal of Animal Ecology 80(4):799-808. https://doi.org/10.1111/ j.1365-2656.2011.01821.X

Bowler, J., M. Betts, I. Bullock, and J. A. Ramos. 2006. Trends in seabird Numbers on Aride Island Nature Reserve, Seychelles 1988-2000. Waterbirds 25(1):26-38. https://doi.org/10.1675/1524-4695 (2002)025[0026:TISNOA]2.0.CO;2

Bristol, R. 2007. Seabirds of the granitic Seychelles: a review of status, threats, uses and conservation. Ostrich 78(2):453-453. https://doi.org/10.2989/OSTRICH.2007.78.2.53.133

Burger, A. E., and A. D. Lawrence. 2000a. Seabird monitoring handbook for Seychelles: suggested methods for censusing seabirds and monitoring their breeding performance. BirdLife Seychelles, Mahé, Seychelles.

Burger, A. E., and A. D. Lawrence. 2000b. Seabird monitoring techniques. BirdLife Seychelles, Mahé, Seychelles.

Catry, T., J. A. Ramos, D. Monticelli, J. Bowler, T. Jupiter, and M. Le Corre. 2009. Demography and conservation of the Whitetailed Tropicbird Phaethon lepturus on Aride Island, Western Indian Ocean. Journal of Ornithology 150:661. https://doi. org/10.1007/s10336-009-0389-Z

Diamond, A. W. 1975. The biology of tropicbirds at Aldabra Atoll, Indian Ocean. Auk 92:16-39. https://doi.org/10.2307/4084415

Diamond, A. W., and R. P. Prŷs-Jones. 1986. The biology of terns nesting at Aldabra Atoll, Indian Ocean, with particular reference to breeding seasonality. Journal of Zoology 210(4):527-548. https://doi.org/10.1111/j.1469-7998.1986.tb03654.x

Dias, M. P., R. Martin, E. J. Pearmain, I. J. Burfield, C. Small, R. A. Phillips, O. Yates, B. Lascelles, P. G. Borboroglu, and J. P. Croxall. 2019. Threats to seabirds: a global assessment. Biological Conservation 237:525-537. https://doi.org/10.1016/j.biocon.2019.06.033

Einoder, L. D. 2009. A review of the use of seabirds as indicators in fisheries and ecosystem management. Fisheries Research 95 (1):6-13. https://doi.org/10.1016/j.fishres.2008.09.024

Hart, L. A., C. T. Downs, and M. Brown. 2016. Sitting in the sun: nest microhabitat affects incubation temperatures in seabirds. Journal of Thermal Biology 60:149-154. https://doi.org/10.1016/ j.jtherbio.2016.07.001

Haverkamp, P. J., J. Shekeine, R. de Jong, M. Schaepman, L. A. Turnbull, R. Baxter, D. Hansen, N. Bunbury, F. Fleischer-Dogley, and G. Schaepman-Strub. 2017. Giant tortoise habitats under increasing drought conditions on Aldabra Atoll: ecological 
indicators to monitor rainfall anomalies and related vegetation activity. Ecological Indicators 80:354-362. https://doi.org/10.1016/ j.ecolind.2017.05.029

Hill, M. J. 2002. Biodiversity surveys and conservation potential of inner Seychelles Islands. Atoll Research Bulletin 495:49-73.

International Union for Conservation of Nature and Natural Resources (IUCN). 2016. Phaethon lepturus (White-tailed Tropicbird). IUCN Red List of Threatened Species, Cambridge, UK. [online] URL: https://www.iucnredlist.org/species/22696645/93576934 \#population

Jaeger, A., M. Connan, P. Richard, and Y. Cherel. 2010. Use of stable isotopes to quantify seasonal changes of trophic niche and levels of population and individual specialisation in seabirds. Marine Ecology Progress Series 401:269-277. https://doi. org/10.3354/meps08380

Jones, K. R., C. J. Klein, B. S. Halpern, O. Venter, H. Grantham, C. D. Kuempel, N. Shumway, A. M. Friedlander, H. P. Possingham, and J. E. M. Watson. 2018. The location and protection status of earth's diminishing marine wilderness. Current Biology 28(15):2506-2512. https://doi.org/10.1016/j. cub.2018.06.010

Leal, G. R., P. P. Serafini, I. Simão-Neto, R. J. Ladle, and M. A. Efe. 2016. Breeding of White-tailed Tropicbirds (Phaethon lepturus) in the western South Atlantic. Brazilian Journal of Biology 76(3):559-567. https://doi.org/10.1590/1519-6984.16514

Le Corre, M. 2001. Breeding seasons of seabirds at Europa Island (southern Mozambique Channel) in relation to seasonal changes in the marine environment. Journal of Zoology 254(2):239-249. https://doi.org/10.1017/S0952836901000759

Le Corre, M., A. Jaeger, P. Pinet, M. A. Kappes, H. Weimerskirch, T. Catry, J. A. Ramos, J. C. Russell, N. Shah, and S. Jaquemet. 2012. Tracking seabirds to identify potential Marine Protected Areas in the tropical western Indian Ocean. Biological Conservation 156:83-93. https://doi.org/10.1016/j.biocon.2011.11.015

Lindenmayer, D., and G. E. Likens. 2018. Effective ecological monitoring. Commonwealth Scientific and Industrial Research Organisation, Clayton, Australia.

Madeiros, J. L. 2008. Breeding success survey of White-tailed Tropicbirds Phaethon on the islands of Bermuda, 2006 to 2008 nesting seasons. Terrestrial Conservation Division, Department of Conservation Services, Bermuda Government, Hamilton, Bermuda. [online] URL: https://www.dcbd.nl/document/breedingsuccess-survey-white-tailed-tropicbird-phaeton-lepturus-catsbyiiislands-bermuda

Malan, G., D. A. Hagens, and Q. A. Hagens. 2009. Nesting success of White Terns and White-tailed Tropicbirds on Cousine Island, Seychelles. Ostrich 80(2):81-84. https://doi.org/10.2989/

OSTRICH.2009.80.2.3.830

Nature Seychelles. 2021. The Seychelles Seabird Group. Nature Seychelles, Mahé, Seychelles. [online] URL: http://www. natureseychelles.org/what-we-do/54-what-we-do/conservationnetworks/79-the-seychelles-seabird-group

Parsons, M., I. Mitchell, A. Butler, N. Ratcliffe, M. Frederiksen, S. Foster, and J. B. Reid. 2008. Seabirds as indicators of the marine environment. ICES Journal of Marine Science 65(8):1520-1526. https://doi.org/10.1093/icesjms/fsn155

Phillips, N. J. 1987. The breeding biology of White-tailed Tropicbirds Phaethon lepturus at Cousin Island, Seychelles. Ibis 129(1):10-24. https://doi.org/10.1111/j.1474-919X.1987.tb03156. $\mathrm{x}$

Piatt, J., A. Harding, M. Shultz, S. Speckman, T. van Pelt, G. Drew, and A. Kettle. 2007. Seabirds as indicators of marine food supplies: Cairns revisited. Marine Ecology Progress Series 352:221-234. https://doi.org/10.3354/meps07078

Prys-Jones, R. P., and C. Peet. 1980. Breeding periodicity, nesting success and nest site selection among Red-tailed Tropicbirds Phaethon Rubricauda and White-tailed Tropicbirds P. Lepturus on Aldabra Atoll. Ibis 122(1):76-81. https://doi.org/10.1111/ j.1474-919X.1980.tb00873.x

R Core Team. 2013. R: A language and environment for statistical computing. R Foundation for Statistical Computing, Vienna, Austria. [online] URL: https://www.R-project.org/

Rabbani, G., A. A. Rahman, and N. Islam. 2010. Climate change and sea level rise: issues and challenges for coastal communities in the Indian Ocean Region. Pages 17-30 in D. Michel and A. Pandya, editors. Coastal zones and climate change. Simson Center, Washington, D.C., USA. [online] URL: https://www. jstor.org/stable/resrep10902.8

Raine, A. F., T. Anderson, S. Driskill, and T. Tippin. 2020. Assessing the breeding phenology of the White-tailed Tropicbird Phaethon lepturus dorotheae on the island of Kaua'i, Hawai'i, using fledgling fallout data. Marine Ornithology 48:23-26. [online] URL: https://sora.unm.edu/sites/default/files/48_1_23-26. pdf

Ramírez, F., I. Afán, L. S. Davis, and A. Chiaradia. 2017. Climate impacts on global hot spots of marine biodiversity. Science Advances 3(2):1-8. https://doi.org/10.1126/sciadv.1601198

Ramos, J. A., J. Bowler, M. Betts, C. Pacheco, J. Agombar, I. Bullock, and D. Monticelli. 2005. Productivity of White-tailed Tropicbird on Aride Island, Seychelles. Waterbirds 28(4):405-410. https://doi.org/10.1675/1524-4695(2005)28[405:POWTOA]2.0.CO;2

Ringler, D., J. C. Russell, and M. Le Corre. 2015. Trophic roles of black rats and seabird impacts on tropical islands: mesopredator release or hyperpredation? Biological Conservation 185:75-84. https://doi.org/10.1016/j.biocon.2014.12.014

Rocamora, G., and A. Skerrett. 2001. Seychelles. Pages 751-768 in L. Fishpool and M. I. Evans, editors. Important bird areas in Africa and associated islands. Pisces Publications/BirdLife International, Cambridge, UK.

Russell, J. C., and M. le Corre. 2009. Introduced mammal impacts on seabirds in the Îles Éparses, Western Indian Ocean. Marine Ornithology 37:121-128. [online] URL: https://www.marineornithology. org/PDF/37_2/37_2_121-128.pdf

Sarmento, R., D. Brito, R. J. Ladle, G. R. da Leal, and M. A. Efe. 2014. Invasive house (Rattus rattus) and brown rats (Rattus norvegicus) threaten the viability of Red-billed Tropicbird (Phaethon aethereus) in Abrolhos National Park, Brazil. Tropical 
Conservation Science 7(4):614-627. https://doi.org/10.1177/194008291400700403

Schaffner, F. C. 1990. Food provisioning by White-tailed Tropicbirds: effects on the developmental pattern of chicks. Ecology 71:375-390. https://doi.org/10.2307/1940275

Schaffner, F. C. 1991. Nest-site selection and nesting success of White-tailed Tropicbirds (Phaethon lepturus) at Cayo Luis Pena, Puerto Rico. Auk 108:911-922. [online] URL: https://sora.unm. edu/sites/default/files/journals/auk/v108n04/p0911-p0922.pdf

Schreiber, R. W., and R. B. Clapp. 1987. Pelecaniform feeding ecology. Pages 173-188 in J. P. Croxall, editor. Seabirds: feeding ecology and role in marine ecosystems. Cambridge University Press, New York, New York, USA.

Skerrett, A., I. Bullock, and T. Disley. 2001. Birds of Seychelles. Helm field guides, Bloomsbury, New York, New York, USA.

Souchay, G., G. Gauthier, and R. Pradel. 2013. Temporal variation of juvenile survival in a long-lived species: the role of parasites and body condition. Oecologia 173:151-160. https://doi. org/10.1007/s00442-013-2613-Z

Stonehouse, B. 1962. The tropicbirds (genus Phaethon) of Ascension Island. Ibis 103B(2):124-161. https://doi.org/10.1111/ j.1474-919X.1962.tb07242.X

Šúr, M., N. Bunbury, and J. Van De Crommenacker. 2013. Frigatebirds on Aldabra Atoll: population census, recommended monitoring protocol and sustainable tourism guidelines. Bird Conservation International 23(2):214-220. https://doi.org/10.1017/ S0959270913000087 